\title{
Partisan Ambivalence and Electoral Decision Making
}

\author{
Stephen C. Craig \\ University of Florida \\ sccraig@ufl.edu
}

\author{
Paulina S. Cossette \\ Washington College \\ pcossette2@washcoll.edu
}

\author{
Michael D. Martinez \\ University of Florida \\ martinez@ufl.edu
}

\begin{abstract}
American politics today is driven largely by deep divisions between Democrats and Republicans. That said, there are many people who view the opposition in an overwhelmingly negative light - but who simultaneously possess a mix of positive and negative feelings toward their own party. This paper is a response to prior research (most notably, Lavine, Johnson, and Steenbergen 2012) indicating that such ambivalence increases the probability that voters will engage in "deliberative" (or "effortful") rather than "heuristic" thinking when responding to the choices presented to them in political campaigns. Looking first at the 2014 gubernatorial election in Florida, we find no evidence that partisan ambivalence reduces the importance of party identification or increases the impact of other, more "rational" considerations (issue preferences, perceived candidate traits, economic evaluations) on voter choice. Our second study uses data from a survey experiment to determine whether a high degree of ambivalence toward one's own party makes voters more responsive to negative attacks against the candidate of that party by his or her opponent. Once again, results do not indicate that partisan ambivalence plays a major role in promoting deliberative as opposed to heuristic thinking among voters. ${ }^{1}$
\end{abstract}

\section{Introduction}

Since the 1950s, scholars have recognized that most citizens identify with one of the major parties and that this attachment provides a powerful cue influencing their attitudes and choice of candidates on Election Day (Campbell et al. 1960). Yet, despite evidence of increased issue consistency in recent years (fewer citizens expressing a mix of liberal, moderate, and conservative opinions; see Abramowitz 2010; Pew Research Center 2017), many rank-and-file partisans do not share the same "extreme" policy views that predominate among their respective party elites (Hill and Tausanovitch 2015; Fiorina 2017). A lack of ideological congruency does not, of course, prevent individuals from positively identifying with a party, nor does it preclude their developing a strong dislike for the opposition. But it does suggest that partisan attachments at the grassroots may be rooted in something other than shared values or policy preferences (Iyengar and Westwood 2015; Achen and Bartels 2016; Mason 2018; Sides, Tesler, and Vavreck 2018) - and, as a result,

\footnotetext{
${ }^{1}$ Portions of this paper were presented at the 2014 annual meetings of the American Political Science Association and the 2015 annual meetings of the Southern Political Science Association. We would like to thank the University of Florida's Bureau of Economic and Business Research and Jim Kitchens for their assistance with the implementation of the two surveys that form the basis for our analysis, and Jason Gainous for his contributions to an earlier version of the paper.
} 
that citizens' feelings toward one party or both may be more equivocal than one would expect during a period of intense discord among both elites and the parties' rank and file.

In fact, numerous studies indicate that many Americans, including a fair number who consider themselves to be either Democrats or Republicans, simultaneously possess both positive and negative feelings about the party with which they identify and/or the one with which they do not, that is, they are ambivalent partisans (Greene 2005; Mulligan 2011; Lavine, Johnston, and Steenbergen 2012; also see Klar and Krupnikov 2016). Further, this blend of positive and negative affect has important consequences. Compared to their univalent counterparts, for example, ambivalent partisans appear more likely to correctly perceive candidate policy positions (Lavine, Johnston, and Steenbergen 2012), more likely to use issues or ideology when evaluating candidates and making vote decisions (Lavine, Johnston, and Steenbergen 2012), more likely to cast a split ballot (Mulligan 2011; but see Thornton 2014; Davis 2015), and less likely to exhibit a variety of party-oriented attitudes and behaviors (Greene 2005). In this paper, we examine voter behavior in two very different contexts to determine whether ambivalence also "motivates individuals to devote additional cognitive resources to judgment tasks" (Lavine, Johnston, and Steenbergen 2012,39), specifically, whether it increases the probability of voters employing deliberative rather than beuristic thinking when responding to the choices presented to them in political campaigns.

\section{Partisan Ambivalence and Electoral Choice}

Scholars have increasingly embraced the idea that people do not always have a single "true" attitude about a given topic; to the contrary, they often possess multiple and even contradictory attitudes that they might draw upon, for example, when thinking about a policy issue or deciding which candidate to vote for in an election. When someone's evaluations, beliefs, or emotions concerning an attitude object are in conflict or, more simply, when that person simultaneously possesses positive and negative evaluations of an attitude object, $s /$ he can be described as being ambivalent (Kaplan 1972; Alvarez and Brehm 1995). Prior studies have examined ambivalence across a range of issues, including abortion (Alvarez and Brehm 1995; Craig, Kane, and Martinez 2002), gay rights (Craig et al. 2005), and social welfare (Zaller and Feldman 1992; Gainous 2008).

Social and political psychologists who study the consequences of ambivalence have posited that it tends to decrease one's reliance on heuristics (or cognitive traps) while increasing thoughtful deliberation and the use of a broader array of information in decision making (Hochschild 1993; Jonas, Diehl, and Bröemer 1997; Guarana and Hernandez 2016). While they were not the first to examine partisan ambivalence (Basinger and Lavine 2005; Greene 2005), Lavine, Johnston, and Steenbergen (2012) apply this general idea to electoral decision making and explain how and why ambivalent voters may come to think more deeply and thoroughly than others when making political judgments. These authors suggest that partisanship functions both as a stable psychological construct based on affective attachment to the party, and as a temporal 
summary judgment of party performance. In line with theories of cognitive consistency (Festinger 1957), they assert that citizens strongly prefer there to be harmony between attachment and summary judgment. When the information flow regarding one's own party trends negative, the ability to maintain harmony and to objectively justify their support for that party is compromised. As a result, the individual is likely to become an ambivalent partisan.

Inherent in this argument is the idea that voters are motivated to have "resolve" when it comes to their attitudes; in other words, they prefer to possess an objectively justifiable attitude that avoids ambiguity, uncertainty, and doubt (Kruglanski and Webster 1996) because to experience doubt is unsettling and uncomfortable. The problem here is that if one's partisanship, long thought to be a filter or perceptual screen through which people evaluate the political world (Campbell et al. 1960), is riddled with ambivalence, it may become blurred and the ability to justify one's attitude through the prism of partisanship will no longer be effective. Lavine and colleagues (2012) posit that such a development encourages voters to think more deliberatively about their political options. This argument is framed around the idea that citizens are motivated to find a sufficiency threshold, or level of confidence, when making a decision (Chaiken, Libermanm, and Eagly 1989). Specifically, the sufficiency threshold "provides a commonsensical mechanism for predicting when - and more important, why - decision makers will transition from heuristic to deliberative thinking" (Lavine, Johnston, and Steenbergen 2012,35).

The transition supposedly occurs when partisan cues no longer furnish enough confidence to create a settled or resolved preference in a given judgment option; in short, a high degree of confidence is not present for ambivalent partisans because partisanship no longer serves as an effective heuristic, and so they are compelled to look elsewhere to objectively justify their position. The research presented here offers a re-consideration of this argument by examining the relationship between ambivalence and deliberative thinking in two different electoral settings. In Study 1, we use survey data from the 2014 governor's race in Florida to compare the determinants of candidate choice for ambivalent versus univalent voters. In Study 2, the findings from an Internet experiment allow us to determine whether ambivalence helps to shape voters' reactions to campaign attacks made against a hypothetical incumbent seeking re-election to the U.S. House.

\section{Study 1: Determinants of Voter Choice in a Gubernatorial Election}

The Florida gubernatorial election in 2014 pitted incumbent Republican Governor Rick Scott against Democratic challenger Charlie Crist. This race was unusual in that Crist was himself a former governor, having been elected in 2006 as a Republican following service in the state legislature and as a member of Florida's state cabinet. After being considered as a potential running mate for GOP presidential nominee John McCain in 2008, Crist opted to run for an open U.S. Senate seat rather than seek reelection. Initially thought to be a shoo-in for his party's nomination, he quickly fell behind fellow Republican Marco Rubio in terms of both fundraising and voter support, and chose to drop out of the primary to run as an Independent in the general election. Despite losing that race to Rubio (by 48.9 to 29.7 percent, with Democrat Kendrick Meek 
finishing third), and notwithstanding reservations among some party stalwarts about Crist's Republican roots, the former governor soon emerged as the leading Democratic alternative to Scott in 2014. Indeed, Crist won a two-way primary (against former state senator Nan Rich) with 74.4 percent of the vote before losing in November by the narrow margin of 48.1 to 47.1 percent. $^{2}$ Our analysis tests the argument that ambivalent partisans will tend to think more deeply and thoroughly than others in making political judgments. Specifically, we expect to find that:

- H1: Issue preferences, candidate traits, and economic evaluations are more strongly correlated with candidate choice, and partisanship less so, among voters who express a high degree of ambivalence toward their own party. ${ }^{3}$

Hypothesis 1 is tested using data from a statewide survey of likely voters conducted by the University of Florida's Bureau of Economic and Business Research in early September 2014. The sample was drawn from a list of registered voters provided by a commercial vendor, with likely voters defined as individuals who (a) voted in both the previous gubernatorial election (2010) and the previous presidential election (2012); (b) voted in either 2010 or 2012, and indicated a subjective probability of voting in 2014 of at least 8 out of 10 ; or (c) registered to vote after the 2012 presidential election, and indicated a subjective probability of voting in 2014 of at least 8 out of 10. Respondents were contacted by either landline or cellphone, with at least one callback attempt if needed, and the survey was offered in both English and Spanish. After applying weights to reflect the statewide population in age group, party registration, and media market, our effective sample size is 916.52 . Table A1 in the online appendix shows the sample distribution on key demographic variables.

The dependent variable for our analysis is gubernatorial candidate choice ( 41.4 percent Scott vs. 36.6 percent Crist). Similar to our previous work (Craig, Kane, and Martinez 2002; Craig et al. 2005), partisan ambivalence was measured by asking respondents to indicate both how positively and how negatively they viewed each party (see Thompson, Zanna, and Griffin 1995):

Next are some questions asking how you feel about the two major political parties in American politics today. First, we are going to ask about how positive you feel, then how negative you feel. Please rate each party based solely on how positively you feel about it, while IGNORING OR SETTING ASIDE for the moment any negative feelings you may also have. First, the Republican Party. Would you say you have no positive feelings, some positive

\footnotetext{
${ }^{2}$ See https://results.elections.myflorida.com/Index.asp?ElectionDate $=11 / 4 / 2014 \& D A T A M O D E=($ retrieved $6 / 3 / 19)$. Scott was subsequently elected to the U.S. Senate in 2018, unseating three-term incumbent Bill Nelson. ${ }^{3}$ While a similar pattern should logically be evident among those who harbor mixed feelings about the opposing party, our data suggest that out-party ambivalence is uncommon in American politics today (see Figures 1 and 2).
} 
feelings, generally positive feelings, or extremely positive feelings?

Respondents were asked a similar question tapping their positive feelings toward the Democratic Party and then, after some filler, asked how negatively they felt (setting aside positive feelings) about each party. Answers were coded from 1 (no positive/negative feelings) to 4 (extremely positive/negative feelings), with an ambivalence score for each party calculated as

$$
\begin{aligned}
& \text { Democratic Ambivalence }=[(\text { Dem Pos }+ \text { Dem Neg }) / 2]-\mid \text { Dem Pos }- \text { Dem Neg } \mid \\
& \text { Republican Ambivalence }=[(\text { Rep Pos }+ \text { Rep Neg }) / 2]-\mid \text { Rep Pos }- \text { Rep Neg } \mid
\end{aligned}
$$

This algorithm yields a "similarity-intensity" (SIM) score in which ambivalence can range from a low of -0.5 , reflecting extremely positive and no negative feelings (or vice versa), to +4.0 , reflecting extremely positive and extremely negative feelings toward the same party. ${ }^{4}$

At a time of heightened partisan polarization, and in the context of a bitter campaign between two well-known (if not especially well-liked; see Martinez 2015) candidates, we might expect that overall levels of ambivalence would be low. This is not the case, as our results reveal a moderate amount of ambivalence toward each party (a mean SIM score of 0.84 for Democrats and 0.99 for Republicans). As shown in Figure 1, however, ambivalence is much more often directed at one's own party than at the opposition; that is, to the extent that Republicans and Democrats possess both positive and negative feelings (something that is more common among weak identifiers and leaners than among strong partisans), those feelings are almost always directed at their own party. In contrast, feelings toward the opposition tend to be univalent and highly negative (again, primarily among strong identifiers on both sides of the aisle).

\footnotetext{
${ }^{4}$ We should point out that our measurement approach is different from that employed by Lavine and his various co-authors. For Basinger and Lavine (2005) and many other scholars (Rudolph and Popp 2007; Mulligan 2011; Thornton 2014; Davis 2015), partisan ambivalence is considered to be high when an individual's evaluations of the Democrats and the Republicans are, comparatively speaking, mixed or inconsistent. For Lavine, Johnston, and Steenbergen (2012), however, partisan ambivalence is high when one's evaluations are inconsistent with his/her partisan identity, e.g., as when a Democrat likes some things about the Republicans and/or dislikes some things about the Democrats. In contrast, we look for evidence of mixed feelings toward each party separately - and, specifically, for evidence that someone has both positive and negative feelings about his/her own party (which is about the only form in which such ambivalence can be found in today's politics). Also, whereas others have used the party or candidate likes/dislikes (Basinger and Lavine 2005; Lavine, Johnston, and Steenbergen 2012), Democratic and Republican feeling thermometers (Johnson 2014), or other closed-ended questions (Greene 2005 ) to measure ambivalence, our approach is more common to experimental research in social psychology than to survey-based studies in political science (but see Craig, Kane, and Martinez 2002; Craig et al. 2005; Gainous 2008).
} 


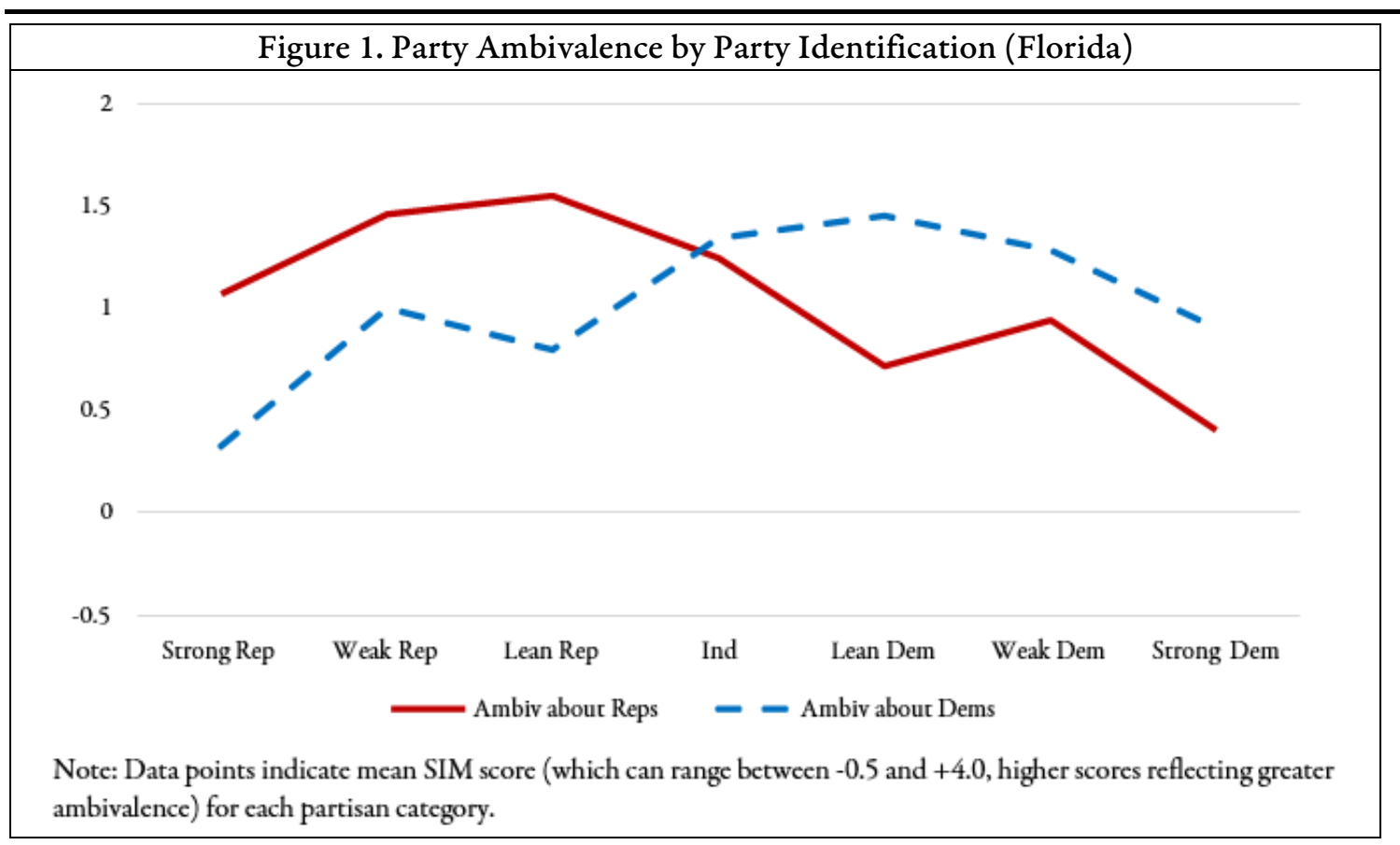

The following analysis excludes respondents for whom ambivalence toward their own party was undefined (pure Independents, third-party identifiers, and those who failed to answer the party identification question), as well as two Republicans and one Democrat who were indifferent (holding no positive or negative feelings) toward their party. ${ }^{5}$ For everyone else: (a) low ambivalence is indicated by a SIM score of -0.5 or 0 , (b) high ambivalence by a score of 2.0 or higher, and (c) medium ambivalence by a score in between those ranges. Counting leaners as partisans, Table 1 shows the distribution of in-party ambivalence for Democrats, Republicans, and the two combined.

Table 1. In-Party Ambivalence by Party Identification (Florida)

\begin{tabular}{|c|c|c|c|}
\hline & Democrats & Republicans & Both \\
\hline Low $($ SIM $\leq 0)$ & $26.4 \%$ & $16.2 \%$ & $21.0 \%$ \\
\hline Medium & 48.4 & 59.2 & 54.1 \\
\hline $\operatorname{High}(\operatorname{SIM} \geq 2)$ & 25.3 & 24.7 & 25.0 \\
\hline Number of cases & 361 & 400 & 761 \\
\hline \multicolumn{4}{|c|}{$\begin{array}{l}\text { Data are from the September } 2014 \text { Florida survey of likely voters, conducted by the University of } \\
\text { Florida's Bureau of Economic and Business Research. Respondents who say they lean toward one party } \\
\text { or the other are classified as partisans. }\end{array}$} \\
\hline
\end{tabular}

\footnotetext{
${ }^{5}$ Although we recognize the conceptual distinction between ambivalence and indifference (Basinger and Lavine 2005; Thornton 2011, 2014; Davis 2015), the paucity of identifiers in the Florida sample who expressed neither positive nor negative feelings toward their party precludes analyzing these individuals separately.
} 
If, as previous research suggests (Lavine, Johnston, and Steenbergen 2012) and has been hypothesized in $\mathrm{H} 1$, ambivalence creates cognitive discomfort that motivates a deeper (or more "effortful"; see Rudolph and Popp 2007) processing of information, we should observe stronger correlations between vote preference (on the on hand) and issue preferences, trait perceptions, and economic evaluations (on the other) - and a weaker correlation between vote preference and party ID - among individuals who possess mixed feelings toward the party with which they identify. Among our independent variables, a factor analysis of respondents' preferences on six issues revealed two dimensions, together accounting for 57 percent of the common variance in a varimax rotation: economic-plus (the Affordable Care Act, minimum wage, Medicaid expansion, immigration reform) and cultural (medical marijuana, same-sex marriage). ${ }^{6}$

We also compared respondents' perceptions of the two candidates on each of five traits (can be trusted, understands the problems of people like me, provides leadership, intelligent, honest and ethical) to determine a relative candidate evaluation. ${ }^{7}$ Evaluations on all five traits loaded onto a single scale, so we calculated a single relative trait evaluation index that ranged from -5 (for those who ranked Crist higher on all five traits) to +5 (for those who ranked Scott higher on all five). Finally, economic evaluations were captured by a single question regarding Florida's economy; scores ranging from 0 ("It will be a long time before the economy recovers") to 1 ("Florida's economy is recovering").

$\mathrm{H} 1$ proposes that individuals who are ambivalent about their party are less likely to be guided by a party heuristic and more apt to vote based on other, more "rational" considerations (Lavine, Johnston, and Steenbergen 2012, 122). A preliminary test of this argument is presented in Table 2, which shows the bivariate correlations between vote choice and (a) partisanship, (b) issue preferences, (c) candidate trait assessments, and (d) economic evaluations for each level of in-party ambivalence. Neither aspect of $\mathrm{H} 1$ receives much support. First, we expected to find the strongest association between party ID and vote among respondents with the least ambivalence toward their party; instead, it occurs among those in the medium-ambivalence group. We further anticipated that high ambivalence would yield the strongest correlations between vote choice and the other independent variables - a pattern that is seen only for economic evaluations, where the relationship is weak to nonexistent across all ambivalence categories. For issue preferences (both dimensions) and candidate trait assessments, the strongest correlations with vote choice arefound among respondents who express low and/or medium rather than high levels of in-party ambivalence. We also ran a series of multivariate logit models (details of which are summarized in Tables A3, A4, and A5 in our supporting materials) and found, if anything, even less support

\footnotetext{
${ }^{6}$ Question wordings for both surveys employed in this paper are provided in online Appendix B. Scores on the first dimension range from 0 to 4 , and on the second from 0 to 2, with higher scores reflecting more conservative attitudes.

7 For example, someone who believed that "can be trusted" described Crist but not Scott was scored as favoring Crist on that trait; a respondent who believed that "can be trusted" described neither Scott nor Crist (or less commonly, both) was scored as seeing no difference.
} 
for $\mathrm{H} 1$ than is provided by the bivariate correlations in Table 2 .

Table 2. Correlations with Candidate Preference, by In-Party Ambivalence (Florida)

\begin{tabular}{|l|c|c|c|c|}
\hline & Overall & Low Ambiv & Med Ambiv & High Ambiv \\
\hline Party Identification & $0.748^{*}$ & $0.720^{*}$ & $0.791^{*}$ & $0.695^{*}$ \\
\hline Economic-Plus Issues & $0.657^{*}$ & $0.667^{*}$ & $0.689^{*}$ & $0.569^{*}$ \\
\hline Cultural Issues & $0.373^{*}$ & $0.258^{*}$ & $0.415^{*}$ & $0.373^{*}$ \\
\hline Candidate Traits & $0.864^{*}$ & $0.892^{*}$ & $0.883^{*}$ & $0.818^{*}$ \\
\hline Economic Evaluations & 0.050 & 0.025 & 0.060 & 0.062 \\
\hline
\end{tabular}

${ }^{*} p<.05$

Data are from the September 2014 Florida survey of likely voters, conducted by the University of Florida's Bureau of Economic and Business Research. Respondents who say they lean toward one party of the other are classified as partisans. Table entries indicate the bivariate $r$ between candidate preference and party identification, issue position, trait assessments, and economic evaluations among all respondents, and among those with low, medium, and high levels of ambivalence toward their own party.

According to Lavine, Johnston, and Steenbergen (2012, 122), ambivalence undercuts "the judgmental confidence that citizens typically derive from partisan cues," thereby leading them to "turn away from these perceptual anchors and pay more attention to the particulars." An analysis of the 2014 Florida gubernatorial race provides little reason to believe that this might be the case. To the extent that partisan ambivalence existed in our sample, it was directed overwhelmingly at one's own party. Contrary to expectations, however, high levels of in-party ambivalence did not motivate citizens to employ deliberative rather than heuristic thinking when responding to the choices presented to them in 2014. This finding does not settle the question, of course. In our second study, we investigate whether ambivalence shapes the way in which voters respond when confronted with negative information about their party's candidate.

\section{Study 2: Ambivalence and Voter Response to Negative Campaigning}

The communications strategy of many modern campaigns focuses more on disparaging one's opponent than on emphasizing one's own strengths as a candidate. The reason is simple: Political professionals almost uniformly believe that negative campaigning is effective (Mattes and Redlawsk 2014,30), if not all of the time then at least under certain circumstances. While there is no shortage of anecdotal evidence to suggest that they are correct, academic studies have yielded mixed results regarding the persuasive effects of campaign ads generally (Fowler, Franz, and Ridout 2016), and of negative advertising or other forms of negative campaigning in particular (Geer 2006; Lau and Rovner 2009; Fridkin and Kenney 2011; Mattes and Redlawsk2014; Banda and Windett 2016; Malloy and Pearson-Merkowitz 2016).

It seems likely that the inconsistent findings of this literature are due at least in part to the fact that negativity lies in the eye of the beholder, that is, "whether a tactic, a candidate, or a 
campaign is [perceived as] negative depends on whose ox is being gored" (Sigelman and Kugler 2003, 144; also see Lipsitz and Geer 2017). The fact that self-identified partisans react differently to attacks coming from the other side than they do to criticism by candidates of their own party should therefore come as no surprise (Ansolabehere and Iyengar 1995; Stevens et al. 2015). What we seek to determine is whether voters with ambivalent feelings about their party are more open to persuasion than those whose feelings are more uniformly positive. The idea here is simply that ambivalent partisans will be, relatively speaking, compelled to weigh the content of a negative ad and incorporate it into their own position in order to pass the sufficiency threshold described earlier, thereby attaining the necessary resolve for their personal comfort or satisfaction. ${ }^{8}$ Thus,

- H2: An attack against one's fellow partisan is more effective among voters who express a high degree of ambivalence about their party.

Our emphasis on attacks against co-partisans reflects the fact that, all else equal (as is the case in our experimental simulation), few identifiers will be moved by an attack on the opponent because most do not plan to vote for that candidate in the first place, i.e., there is a ceiling (or floor) effect that leaves little room for a meaningful erosion of support.

Study 2 results are based on a controlled experiment involving a sample of 660 individuals who participated in an Internet survey conducted between July 9-14, 2015. ${ }^{9}$ Respondents were randomly assigned to one of sixteen treatment groups ${ }^{10}$ and asked to complete a background questionnaire that measured basic demographics, partisanship, issue attitudes, and a number of other political orientations. They were then told to imagine that it was the fall of 2016 , and one of the races on their ballot involved a congressional matchup between an incumbent seeking a third term and an experienced challenger who had served in both local office and the state legislature. After reading short biographies, ${ }^{11}$ participants were asked to indicate a preference ("Based on theinformation you currently have, which candidate would you vote for if the election were held today?") and to

\footnotetext{
${ }^{8}$ Essentially, we are looking for evidence that "the degree to which effortful thinking is biased or objective [depends] largely on the extent to which party identification reduces the gap between actual and desired judgment confidence" (Lavine, Johnston, and Steenbergen 2012, 37).

${ }^{9}$ Data were provided by qSample (www.qSample.com) from panels consisting of millions of pre-screened members who have been recruited to participate in a variety of research studies. Respondents for this study were drawn from the national panel of registered voters in a random sample stratified by region. The response rate (RR1) was 66 percent. Although qSample's panel is quite diverse (see Table A7 in our supporting materials), we make no claim that it is representative of registered voters nationwide.

${ }^{10}$ The sixteen groups are summarized in online Table A6. Our randomization process appears to have been successful. No statistically significant differences were observed among members of the sixteen groups with regard to demographics, partisanship, ideological self- identification, issue positions, or baseline candidate preferences (vote choice, favorability). Thus, if differences are found across groups after respondents read the attack, we can be confident that these were driven by exposure to the experimental stimulus.

${ }^{11}$ Each candidate's party affiliation and status as either challenger or incumbent was specified, but otherwise the biosketches were crafted in such a way as to ensure that the two portrayals were essentially equivalent (including the fact that both candidates were men).
} 
rate both contenders on a 7-point scale ranging from "very unfavorable" (1) to "very favorable" (7); answers to the vote and incumbent favorability questions serve as the dependent variablesfor our analysis. Participants subsequently read what was described as a direct-mail attack (see below) by the challenger and again registered their vote choice and candidate assessments. In a final stage of the experiment not reported here, each person read one of two responses (positive or negative/counterattack) by the target candidate and answered the vote and favorability questions a third time.

Our analysis examines the effects of attacks in four policy areas that represent areas of sharp conflict between the Republican and Democratic parties: inequality, immigration, national security, and the environment. The content of issue-based ads will usually vary with the identity of the attacker, e.g., a Democratic-sponsored negative ad about inequality will criticize different policy stands, reference different symbols, and propose different solutions than a Republicansponsored negative ad on the same topic. Our challenge, then, was to create two more-or-less equivalent (in terms of their tone, specificity, credibility, and likely effectiveness) but substantively distinct attacks for each of the four issues, as well as a positive and a negative response to accompany each. A brief summary of these attacks is laid out in Table 3, with a full description provided in our supporting materials. According to Fridkin and Kenney (2011), relevant (containing information on how a politician has influenced/is likely to influence voters' lives) and uncivil (uncertain about where to draw the line, we prefer "hard-hitting") negative ads have the greatest impact on evaluations of a targeted candidate. The allegations made in these ads seem clearly to meet each of these standards.

Table 3. Four Policy-Based Attacks on Incumbent, by Party of Challenger (National)

\begin{tabular}{|c|c|c|}
\hline Attack Type & $\begin{array}{l}\text { Democratic Challenger Attack on } \\
\text { Republican Incumbent }\end{array}$ & $\begin{array}{l}\text { Republican Challenger Attack on } \\
\text { Democratic Incumbent }\end{array}$ \\
\hline Inequality & $\begin{array}{l}\text { Incumbent represents "the powerful few, not } \\
\text { you." } \\
\text { - supports the fantasy that lowering taxes on } \\
\text { the rich will benefit working families } \\
\text { - opposes a higher minimum wage, child- care } \\
\text { tax credits, and paid sick leave policies } \\
\text { - opposes a federal jobs program to rebuild } \\
\text { our nation's crumbling infrastructure } \\
\text { - is unconcerned that the richest } 3 \% \text { hold } \\
\text { more than half of the nation's wealth }\end{array}$ & $\begin{array}{l}\text { Incumbent stirs up "class warfare" with ideas } \\
\text { that are outdated and ineffective. } \\
\text { - ignores the fact that more people are living in } \\
\text { poverty than before Obama was elected } \\
\text { - thinks that higher taxes, more spending, and } \\
\text { bigger government will solve every problem } \\
\text { - supports rules and regulations that make it } \\
\text { harder for businesses to create new jobs } \\
\text { - opposes policies that would help to create } \\
\text { opportunities for all citizens to have a better life }\end{array}$ \\
\hline
\end{tabular}




\begin{tabular}{|c|c|c|}
\hline Immigration & $\begin{array}{l}\text { Incumbent should stop "political } \\
\text { grandstanding" on this important issue. } \\
\text { - proposes to deport immigrant children } \\
\text { - opposes a "path to citizenship" even for } \\
\text { those with high-tech skills that could help to } \\
\text { jumpstart the American economy } \\
\text { - is willing to risk a government shutdown if } \\
\text { restrictive new laws are not adopted } \\
\text { - falsely claims that immigrants have taken } \\
\text { millions of jobs away from American workers }\end{array}$ & $\begin{array}{l}\text { Incumbent is "the best friend that an illegal } \\
\text { alien ever had." } \\
\text { - supports giving amnesty to illegals and even } \\
\text { allowing them to become citizens } \\
\text { - objects to building a fence along our southern } \\
\text { border and hiring more federal border agents } \\
\text { - wants to give illegals taxpayer-funded benefits } \\
\text { such as drivers licenses and Social Security } \\
\text { - opposes state governments penalizing } \\
\text { businesses that hire undocumented workers }\end{array}$ \\
\hline Environment & $\begin{array}{l}\text { Incumbent "has his head in the sand about } \\
\text { climate change." } \\
\text { - fails to recognize that it is a serious threat to } \\
\text { our national security } \\
\text { • ignores scientific evidence of human } \\
\text { responsibility for warming trends } \\
\text { - opposes stricter limits on carbon pollution } \\
\text { and then accepts campaign money from the } \\
\text { polluters } \\
\text { - inaction on the issue puts our families, } \\
\text { homes, and businesses at risk now and in the } \\
\text { future }\end{array}$ & $\begin{array}{l}\text { Incumbent supports policies that "cost billions } \\
\text { of dollars, lead to higher energy prices, and } \\
\text { destroy American jobs." } \\
\text { - voted against the Keystone XL pipeline that } \\
\text { would create thousands of new American jobs } \\
\text { - supports a moratorium on oil and gas } \\
\text { exploration in the Gulf of Mexico, which also } \\
\text { costs jobs } \\
\text { - wants to impose stricter pollution controls } \\
\text { that will prove burdensome for businesses } \\
\text { - is beholden to environmental extremists and } \\
\text { has little regard for anyone's job but his own }\end{array}$ \\
\hline Attack Type & $\begin{array}{l}\text { Democratic Challenger Attack on } \\
\text { Republican Incumbent }\end{array}$ & $\begin{array}{l}\text { Republican Challenger Attack on } \\
\text { Democratic Incumbent }\end{array}$ \\
\hline $\begin{array}{l}\text { National } \\
\text { Security }\end{array}$ & $\begin{array}{l}\text { Incumbent hasn't learned from "mistakes of } \\
\text { the past." } \\
\text { - supports a reckless increase in defense } \\
\text { spending that will dramatically increase our } \\
\text { national debt } \\
\text { - believes that the U.S. invasion of Iraq in } \\
2003 \text { was worth the high cost in money and } \\
\text { lives lost } \\
\text { - is prepared to send ground troops to fight } \\
\text { terrorist groups in the Middle East } \\
\text { - says that the U.S. should act unilaterally in } \\
\text { taking military action if other countries } \\
\text { choose not to get involved }\end{array}$ & $\begin{array}{l}\text { Incumbent is "dangerously wrong" on national } \\
\text { security. } \\
\text { - does not grasp the threat posed by radical } \\
\text { terrorists and the spread of WMDs } \\
\text { - supports deep cuts in military spending that } \\
\text { would leave our troops without the equipment } \\
\text { and logistical support they need } \\
\text { - is willing to negotiate with foreign nations } \\
\text { even if they have ties to terrorist groups } \\
\text { - thinks we should ask other nations for } \\
\text { permission before acting to protect our own } \\
\text { security }\end{array}$ \\
\hline
\end{tabular}


Taking everything into account, our full experimental design was as follows: 4 (number of issues) X 2 (number of party attacks/responses on each issue) X 2 (response type, positive or negative $)=$ a total of 16 treatment groups. For present purposes, however, we will not examine differences by either issue or response type, thereby reducing the effective number of groups from 16 to 2: self-identified Democrats and self-identified Republicans (including leaners) who were exposed to an attack against the candidate of their party. To test our hypotheses, these two sets of respondents were pooled.

We created three separate measures of partisan ambivalence, each of which yields similar conclusions. The first of these, labeled affective ambivalence, is based on the same questions about positive and negative feelings toward the parties used in the Florida survey. To measure emotional ambivalence toward the parties (cf. Citrin and Luks 2005), respondents were asked, "Has the Democratic Party - because of its policies, its leaders, or something else the party has done - ever made you feel ... a afraid, proud, angry, enthusiastic, anxious, hopeful?" The identical 6-item battery was then repeated for the Republican Party. ${ }^{12} \mathrm{~A}$ third index (which we will call evaluative ambivalence to distinguish it from the affective measure) was patterned after the open-ended likes and dislikes questions used by Lavine (2001) and others. Respondents were asked if there was anything they liked and disliked about each party and offered the following options: good/bad candidates, good/bad policy ideas, has done a good/bad job when in office, all of the above, and "nothing in particular." 13

As with Florida voters, respondents in our internet sample exhibited a fair amount of partisan ambivalence. Similar to what we observed in Study 1, however, each type of ambivalence (affective, emotional, evaluative) was usually directed at one's own party rather than at the opposition (toward whom feelings tended to be highly negative, especially among strong identifiers; see Figure 2 and Table 4 for affective ambivalence, Figures A1-A2 in our supporting materials for the other two measures) - something along the lines of: We're not perfect, but the other guys are worse. It is ambivalence about one's own party that is expected to promote an "effortful"

\footnotetext{
${ }^{12}$ Response options to these questions were never (coded 0), rarely, occasionally, fairly often, and very often (coded 4). The mean score for proud, enthusiastic, and hopeful reflected positive emotion for each party, while the mean score for afraid, angry, and anxious reflected negative emotion. Emotional ambivalence for each party was then calculated using the same algorithm described earlier for affective ambivalence. Distributions are reported in Tables A11 and A12 in our supporting materials.

${ }^{13}$ Answers were coded as 0 for nothing, 1 for either candidates, policy ideas, or performance, and 2 for all the above, and evaluative ambivalence was calculated for each party based on the same algorithm as before. Distributions are reported in online Tables A12 and A14. Not surprisingly, our various measures are positively correlated: affective-emotional $(r=.435$ for ambivalence toward the Republicans and .454 for ambivalence toward the Democrats), affective- evaluative ( $r=.382$ and .399 , respectively) and emotional-evaluative (.463 and .480, respectively). There also is a positive correlation ( $r=.305$ to .536$)$ between ambivalence toward the Republicans and ambivalence toward the Democrats within each of the three types, and a positive but less strong correlation $(r$ $=.097$ to .266 ) between ambivalence toward the Republicans and ambivalence toward the Democrats across types; see Table A15 in our supporting materials.
} 
processing of information and thereby to play a significant role in shaping citizens' reactions to negative campaign communications. ${ }^{14}$

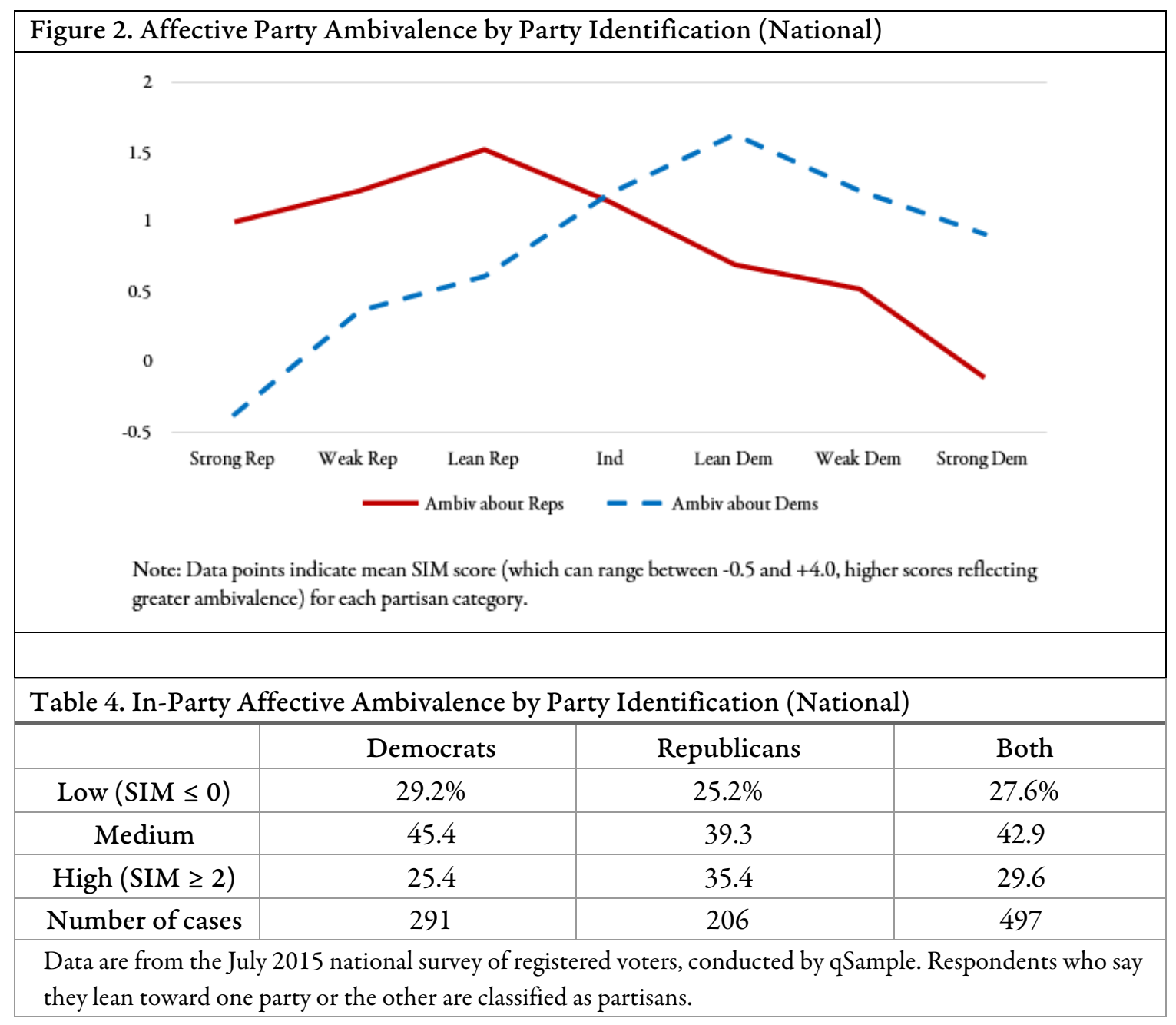

In addition to partisan ambivalence, we examine several other factors (see Appendix B in our supporting materials for question wordings) that could plausibly moderate the effects of a negative ad. Our expectations are that:

- H3: An attack against one's fellow partisan is more effective among voters whose policy views on the issue addressed in the attack are in line with the charges leveled in the attack.

- H4: An attack against one's fellow partisan is more effective among voters who believe that candidates "need to criticize their opponents because it is important for voters to know the strengths and weaknesses of all candidates."

\footnotetext{
${ }^{14}$ As before, the analyses for Study 2 exclude pure Independents, third-party identifiers, and those who failed to answer the party identification question.
} 
- H5: An attack against one's fellow partisan is more effective among voters who believe that the specific ad to which they were exposed was either "negative but acceptable" or "not really negative at all."

- H6: An attack against one's fellow partisan is more effective among voters who report that they follow what's going on in government and public affairs "only now and then" or "hardly at all."

The reasoning behind $\mathrm{H} 3$ is straightforward: Why would voters be motivated to cast an issue-based vote (or in our case, to be moved by a policy-based attack) if they disagree with the substance of the attack ${ }^{15}$ Further, although there is evidence indicating that negative ads may be more effective among voters who express a lower tolerance for campaign negativity (Fridkin and Kenney 2011), we think it makes more sense to expect that, as a general rule, the opposite will be the case (hence $\mathrm{H} 4$ and H5). Finally, H6 is in line with prior studies that have found the persuasive effects of campaign ads to be greater among those who are less politically engaged and therefore less likely to have strongly held policy views in the first place (e.g., Fridkin and Kenney 2004; Valentino, Hutchings, and Williams 2004; Franz and Ridout 2007).

If, as prior research suggests (Lavine, Johnston, and Steenbergen 2012) and is predicted by $\mathrm{H} 2$, ambivalence creates cognitive discomfort that motivates a deeper (or more "effortful") processing of information, we should observe stronger effects of the challenger's attack among incumbent co-partisans who express higher levels of ambivalence toward their party. Our experimental results provide no support for this argument. For affective ambivalence, Table 5 indicates that the attack ad was effective in changing, at least temporarily (Gerber et al. 2011; Hill et al. 2013; Bartels 2014), both vote intention and attitudes about the candidates among all three groups of respondents. Specifically, electoral support for the incumbent dropped between 10.9 and 17.8 percentage points, and mean incumbent favorability declined between 0.261 and 0.680 points (on a 7-point scale) - all changes that were statistically significant at $p \leq .02$. However, contrary to $\mathrm{H} 2$, Column 1 of Table 5 shows that diminished support for the incumbent was not most pronounced among those who exhibited a high degree of ambivalence toward their party $(p$ $>.05$ for differences between all three groups). ${ }^{16}$ Further, Column 2 shows that the decline in

\footnotetext{
${ }^{15}$ We initially suspected that the effect of policy consistency might depend on how salient an issue was to the respondent, such that respondents whose policy views were more consistent with the attack charges and who believed the issue in the ad was highly salient would be more likely to find the attack persuasive. However, when we included in our regression models (see below) an interaction term to reflect this we found that neither the interaction nor the individual consistency and salience variables were statistically significant. Such a result may reflect the fact that our sample does not include enough cases, distributed appropriately across these variables, to detect the differential effects. See Tables A18-A19 in our supporting materials for more details.

${ }^{16}$ The coding scheme used to classify respondents as either high, medium, or low on ambivalence is identical to that employed in the Florida survey. It is worth noting that prior to the attack, based solely on the biographical information provided, at least 89 percent of respondents at each level of affective, emotional, and evaluative ambivalence said they would vote for the candidate of their party.
} 
incumbent favorability was greater $(p<.05)$ among those with low affective ambivalence than among their high-ambivalence counterparts. Differing only slightly in the particulars, results for both emotional and evaluative ambivalence (shown in Tables A18 and A19 in our supporting materials) also are inconsistent with the expectations laid out in $\mathrm{H} 2$. Most notably, there is not a single instance where the magnitude of post-attack change is significantly $(p<.05)$ different for high-vs. low- ambivalence respondents.

Table 5. Effectiveness of Campaign Attack, by Levels of Affective Ambivalence (National, Partisans Only)

\begin{tabular}{|c|c|c|c|c|c|}
\hline \multicolumn{6}{|c|}{ Ambivalence about Incumbent's Party, Incumbent Co-Partisans } \\
\hline \multirow{6}{*}{ 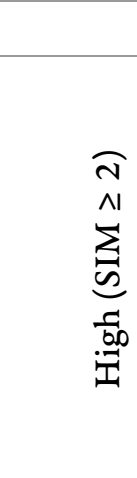 } & \multicolumn{3}{|c|}{ Vote for Incumbent } & \multicolumn{2}{|c|}{ Favorability, Incumbent } \\
\hline & & $N$ & Prop & $N$ & Mean \\
\hline & Baseline eval. & 73 & $\begin{array}{c}0.932 \\
(0.030)\end{array}$ & 73 & $\begin{array}{c}5.137 \\
(0.118)\end{array}$ \\
\hline & $\begin{array}{l}\text { Post-attack } \\
\text { eval. }\end{array}$ & 73 & $\begin{array}{c}0.753 \\
(0.050)\end{array}$ & 73 & $\begin{array}{c}4.836 \\
(0.168)\end{array}$ \\
\hline & diff & & $\begin{array}{l}-0.178 \\
(0.058)\end{array}$ & & $\begin{array}{l}-0.301 \\
(0.136)\end{array}$ \\
\hline & & \multicolumn{2}{|c|}{$p=0.002$} & \multicolumn{2}{|c|}{$p=0.015$} \\
\hline \multirow{4}{*}{$\stackrel{\Xi}{\Xi}$} & Baseline eval. & 92 & $\begin{array}{c}0.913 \\
(0.029)\end{array}$ & 92 & $\begin{array}{c}5.109 \\
(0.135)\end{array}$ \\
\hline & $\begin{array}{l}\text { Post-attack } \\
\text { eval. }\end{array}$ & 92 & $\begin{array}{c}0.804 \\
(0.041)\end{array}$ & 92 & $\begin{array}{c}4.848 \\
(0.154)\end{array}$ \\
\hline & diff & & $\begin{array}{l}-0.109 \\
(0.051)\end{array}$ & & $\begin{array}{l}-0.261 \\
(0.125)\end{array}$ \\
\hline & & \multicolumn{2}{|c|}{$p=0.017$} & \multicolumn{2}{|c|}{$p=0.020$} \\
\hline \multirow{4}{*}{$\begin{array}{l}\text { o } \\
\text { v1 } \\
\sum \\
\vdots \\
0 \\
0 \\
0 \\
0 \\
0\end{array}$} & Baseline eval. & 76 & $\begin{array}{c}0.908 \\
(0.033)\end{array}$ & 75 & $\begin{array}{c}5.600 \\
(0.148)\end{array}$ \\
\hline & $\begin{array}{l}\text { Post-attack } \\
\text { eval. }\end{array}$ & 75 & $\begin{array}{c}0.747 \\
(0.050)\end{array}$ & 75 & $\begin{array}{c}4.290 \\
(0.206)\end{array}$ \\
\hline & diff & & $\begin{array}{l}-0.161 \\
(0.060)\end{array}$ & & $\begin{array}{l}-0.680 \\
(0.168)\end{array}$ \\
\hline & & \multicolumn{2}{|c|}{$p=0.004$} & \multicolumn{2}{|c|}{$p=0.000$} \\
\hline \multicolumn{6}{|c|}{ Significance of Differences in Effects Across Levels of Ambivalence } \\
\hline \multicolumn{2}{|c|}{ Moderate vs. Low } & \multicolumn{2}{|c|}{ n.s. } & \multicolumn{2}{|c|}{$p=0.024$} \\
\hline \multicolumn{2}{|c|}{ High vs. Low } & \multicolumn{2}{|c|}{ n.s. } & \multicolumn{2}{|c|}{$p=0.041$} \\
\hline \multicolumn{2}{|c|}{ Moderate vs. High } & \multicolumn{2}{|c|}{ n.s. } & \multicolumn{2}{|c|}{ n.s } \\
\hline \multicolumn{6}{|c|}{$\begin{array}{l}\text { Data are from a July } 2015 \text { national survey of registered voters, conducted by qSample. The analysis is based on } \\
\text { paired t-tests. For vote choice, difference is calculated as proportion (post- attack vote) - proportion (baseline } \\
\text { vote). For favorability, difference is calculated as mean (post- attack) - mean (baseline). Significance tests are 1- } \\
\text { tailed. Respondents who say they lean toward one party or the other are classified as partisans. }\end{array}$} \\
\hline
\end{tabular}


The deliberative thinking argument fares no better when we move from t-tests to a multivariate model of vote choice. Counting leaners as partisans (Keith et al. 1986; Magleby and Nelson 2012), the results in Table 6 indicate that none of the three measures of ambivalence had a significant impact on a respondent's post-attack candidate preference. Unsurprisingly, voting for the incumbent at the pre-attack baseline is a strong predictor $(p<.01)$ of one's decision to support the incumbent a second time. Such stability was not, however, universal. In line with our expectations ( $\mathrm{H} 3)$, those whose policy views were generally consistent with the charges made in the attack had a significantly $(p<.01)$ lower probability of voting for the incumbent at T2. ${ }^{17}$ Across all three models, each one-unit increase in policy consistency corresponds to an approximately 25 percent drop (1-.740) in the odds of voting for the incumbent following the attack.

\begin{tabular}{|c|c|c|c|c|c|c|}
\hline & \multicolumn{2}{|c|}{$\begin{array}{c}\text { Affective } \\
\text { Ambivalence }\end{array}$} & \multicolumn{2}{|c|}{$\begin{array}{c}\text { Emotional } \\
\text { Ambivalence }\end{array}$} & \multicolumn{2}{|c|}{$\begin{array}{c}\text { Evaluative } \\
\text { Ambivalence }\end{array}$} \\
\hline & Coeff. & $\begin{array}{c}\text { Odds } \\
\text { Ratios }\end{array}$ & Coeff. & $\begin{array}{c}\text { Odds } \\
\text { Ratios }\end{array}$ & Coeff. & $\begin{array}{c}\text { Odds } \\
\text { Ratios }\end{array}$ \\
\hline $\begin{array}{l}\text { Vote of Incumbent, } \\
\text { Baseline }\end{array}$ & $2.160^{* * *}$ & $8.667^{* * *}$ & $2.164^{* * *}$ & $8.708^{* * *}$ & $2.099^{* * *}$ & $8.157^{* * *}$ \\
\hline $\begin{array}{l}\text { Democratic } \\
\text { Incumbent }\end{array}$ & -0.149 & 0.862 & -0.157 & 0.855 & -0.169 & 0.845 \\
\hline Ambivalence & 0.097 & 1.101 & -0.057 & 0.945 & -0.219 & 0.803 \\
\hline
\end{tabular}

\footnotetext{
${ }^{17}$ Respondents' policy preferences were measured by a pair of questions (see online Appendix B) in each of the four policy domains represented in our experimental treatments: the environment (protecting the environment vs. maintaining jobs and a good standard of living; whether climate change is a serious problem requiring government action; $r=.55$ between these two items), national security (fighting terrorism with force vs. helping poor countries to develop their economies; ensuring peace with superior military power or with diplomacy; $r=.40$ ), immigration (do immigrants strengthen the country or take jobs and end up on welfare; what should be done with undocumented immigrants currently living in the U.S.; $r=.36$ ), and inequality (whether it is the government's business to ensure that money and wealth is more evenly distributed; raising taxes on the wealthy and corporations vs. lowering taxes to promote economic growth; $r=.60$ ). Our measure of "policy consistency" captures the degree to which an individual's views are in line with the charges leveled in the attack, e.g., an immigration conservative who read the Republican attack on that issue would receive a high consistency score. Four additive indices were created, one for each issue, with all responses coded in the same ideological direction and calculated on a scale from 1 to 5; thus, index values range between 2 and 10 (higher scores representing greater agreement between one's policy positions and the charges leveled in the attack, while controlling for the attack's partisan origins).
} 
Table 6 (continued). Effect of Issue-Based Attacks on Vote for Incumbent by Ambivalence Measure (National, Incumbent Co-Partisans)

\begin{tabular}{|c|c|c|c|c|c|c|}
\hline Policy Consistency & $-0.302^{* * *}$ & $0.740^{* * *}$ & $-0.292^{* * *}$ & $0.747^{* * *}$ & $-0.293^{* * *}$ & $0.746^{* * *}$ \\
\hline \multicolumn{7}{|l|}{ Criticize Opponents: } \\
\hline $\begin{array}{l}\text { Avoid criticizing } \\
\text { (feel not so } \\
\text { strongly) }\end{array}$ & 0.057 & 1.058 & 0.102 & 1.107 & 0.118 & 1.125 \\
\hline Mixed, in-between & -0.675 & 0.509 & -0.646 & 0.524 & -0.643 & 0.526 \\
\hline $\begin{array}{l}\text { Need to criticize } \\
\text { (feel not so } \\
\text { strongly) }\end{array}$ & -0.613 & 0.542 & -0.637 & 0.529 & -0.633 & 0.531 \\
\hline $\begin{array}{l}\text { Need to criticize } \\
\text { (feel strongly) }\end{array}$ & 0.753 & 2.123 & 0.741 & 2.098 & 0.828 & 2.288 \\
\hline \multicolumn{7}{|l|}{ Perceptions of Ad: } \\
\hline $\begin{array}{l}\text { Not really negative at } \\
\text { all }\end{array}$ & $-1.866^{* * *}$ & $0.155^{* * *}$ & $-1.858^{* * *}$ & $0.156^{* * *}$ & $-1.816^{* * *}$ & $0.163^{* * *}$ \\
\hline $\begin{array}{l}\text { Negative but } \\
\text { acceptable }\end{array}$ & $-1.875^{* * *}$ & $0.153^{* * *}$ & $1.868^{* * *}$ & $0.154^{* * *}$ & $-1.848^{* * *}$ & $0.158^{* * *}$ \\
\hline \multicolumn{7}{|l|}{ Follow Politics: } \\
\hline Hardly at all & $-1.101^{*}$ & $0.333^{*}$ & $-1.172^{*}$ & $0.310^{*}$ & $-1.200^{*}$ & $0.301^{*}$ \\
\hline Only now and then & -0.465 & 0.628 & -0.529 & 0.589 & -0.619 & 0.539 \\
\hline Some of the time & $-1.129^{* *}$ & $0.323^{* *}$ & $-1.156^{* *}$ & $0.315^{* *}$ & $-1.160^{* *}$ & $0.313^{* *}$ \\
\hline Environment Attack & 0.049 & 1.050 & 0.031 & 1.032 & 0.087 & 1.091 \\
\hline $\begin{array}{l}\text { National Security } \\
\text { Attack }\end{array}$ & 0.312 & 1.366 & 0.312 & 1.366 & 0.405 & 1.500 \\
\hline Immigration Attack & 0.458 & 1.581 & 0.442 & 1.556 & 0.449 & 1.567 \\
\hline Constant & $3.186^{* * *}$ & $24.187^{* * *}$ & $3.319^{* * *}$ & $27.628^{* * *}$ & $3.298^{* * *}$ & $27.048^{* * *}$ \\
\hline$N$ & \multicolumn{2}{|c|}{240} & \multicolumn{2}{|c|}{240} & \multicolumn{2}{|c|}{240} \\
\hline $\mathrm{R}^{2}$ & \multicolumn{2}{|c|}{0.246} & \multicolumn{2}{|c|}{0.245} & \multicolumn{2}{|c|}{0.248} \\
\hline
\end{tabular}


Table 6 (continued). Effect of Issue-Based Attacks on Vote for Incumbent by Ambivalence Measure (National, Incumbent Co-Partisans)

Data are from a July 2015 national survey of registered voters, conducted by qSample. Models are logit models in which the dependent variable is a dummy measuring post-attack vote for the incumbent $(1=$ yes, $0=$ no). Significance tests are 2 -tailed: ${ }^{*} p<.10 ;{ }^{* *} p<.05 ;{ }^{* * *} p \leq .01$. Respondents who say they lean toward one party or the other are classified as partisans.

Perceived negativity and political engagement also are significant predictors of post-attack vote choice. As expected, respondents who believed the attack they viewed was either "negative but acceptable" or "not really negative at all" (H5) were much less likely, compared to those who felt it was "too negative and should not be made" (the reference category, $p<.01$ for both groups) to back the incumbent/target after reading the attack. We find no support, however, for the hypothesis (H4) that an attack will be more effective among individuals who possess a greater tolerance for campaign negativity in general, i.e., who believe that it enables voters to know the weaknesses of candidates that might affect their performance in office. Similarly, the results in Table 6 indicate that the persuasive effects of our policy-based attacks were inconsistent across levels of political engagement: greater among the least engaged ( $\mathrm{H} 6)$ but also those who said they follow government and public affairs "some of the time" (cf. Huber and Arceneaux 2007), weaker among voters who follow politics "only now and then" or "most of the time" (the reference category). Finally, neither the party of the incumbent nor the specific issue discussed in theattack had a significant impact on citizens' vote preferences.

Our tests using incumbent favorability as the dependent variable yield similar (though not identical) results, as shown in the OLS models depicted in Table 7. First, only the affective measure of ambivalence is a significant predictor of change in incumbent favorability from baseline to post- attack - and the direction of that change is opposite of what we hypothesized $(\mathrm{H} 2)$, i.e., respondents who are more ambivalent about their party award the incumbent a larger increase in favorability from T1 to T2 compared to their less ambivalent counterparts $(p<.10)$. Consistent with $\mathrm{H} 3$, we find that voters who have policy views that are more consistent with the charges made in the attack punish incumbents significantly more in all three models compared to respondents with less compatible views $(\mathrm{p}<.05$ for the model using affective ambivalence; $p$ $<.10$ for the others). Finally, the change in incumbent favorability was significantly greater $(p<$ .10) for respondents who read the national security attack compared to those who read the inequality attack (the reference category) in one of our three models. None of the other variables we tested produced statistically significant results. 
Table 7: Effect of Issue-Based Attacks on Incumbent Favorability, by Ambivalence Measure (National, Incumbent Co-Partisans)

\begin{tabular}{|c|c|c|c|}
\hline & $\begin{array}{c}\text { Affective } \\
\text { Ambivalence }\end{array}$ & $\begin{array}{c}\text { Emotional } \\
\text { Ambivalence }\end{array}$ & $\begin{array}{c}\text { Evaluative } \\
\text { Ambivalence }\end{array}$ \\
\hline & Coeff. & Coeff. & Coeff. \\
\hline $\begin{array}{l}\text { Democratic } \\
\text { Incumbent }\end{array}$ & -0.127 & -0.147 & -0.148 \\
\hline Ambivalence & $0.150^{*}$ & -0.004 & 0.033 \\
\hline Policy Consistency & $-0.085^{* *}$ & $-0.073^{*}$ & $-0.074^{*}$ \\
\hline Criticize Opponents & 0.025 & 0.030 & 0.029 \\
\hline $\begin{array}{l}\text { Perceived Ad as } \\
\text { Negative }\end{array}$ & 0.069 & 0.059 & 0.063 \\
\hline Follow Politics & -0.010 & 0.009 & 0.004 \\
\hline Environment Attack & 0.001 & -0.032 & -0.031 \\
\hline $\begin{array}{l}\text { National Security } \\
\text { Attack }\end{array}$ & $0.445^{*}$ & 0.412 & 0.408 \\
\hline Immigration Attack & 0.244 & 0.213 & 0.217 \\
\hline Constant & -0.429 & -0.330 & -0.320 \\
\hline$N$ & 240 & 240 & 240 \\
\hline $\mathrm{R}^{2}$ & 0.05 & 0.04 & 0.04 \\
\hline \multicolumn{4}{|c|}{$\begin{array}{l}\text { Data are from a July } 2015 \text { national survey of registered voters, conducted by qSample. Models are OLS } \\
\text { regressions in which the dependent variable is change in incumbent favorability from baseline to post-attack } \\
\text { (T2 rating - T1 rating). Significance tests are } 2 \text {-tailed: }{ }^{*} p<.10 ;{ }^{* *} p<.05 ;{ }^{* * *} p<.01\end{array}$} \\
\hline
\end{tabular}

One might ask whether the inability to detect effects similar to those reported by Lavine, Johnston, and Steenbergen (2012) reflects differences in our respective measurement strategies. To address this possibility, we replicated their analytic approach using the items that comprise our measure of affective ambivalence (positive/negative feelings). For the incumbent's copartisans, including leaners, we calculated (1) a "conflicting" score equal to own-party negative affect plus opposite-party positive affect, and (2) a "consistent" score equal to own-party positive affect plus opposite-party negative affect. ${ }^{18} \mathrm{We}$ then regressed change in incumbent favorability

${ }^{18}$ For this analysis, all affect scores are re-scaled from zero to one. 
(baseline to post-attack) on the "consistent" score, the "conflicting" score, and, as a control, general political interest. The logic outlined in The Ambivalent Partisan leads us to predict that the attack will be more effective (in terms of lowering incumbent favorability) among respondents with conflicting evaluations, i.e., those with higher levels of partisan ambivalence. Results of the OLS regression were as follows:

\section{Table 8. Results of OLS Regression}

\begin{tabular}{|c|c|c|c|c|c|c|c|c|c|c|}
\hline$\Delta$ Inc Favorability & $\begin{array}{c}-0.138 \\
(.049)\end{array}$ & + & Consistent & $\begin{array}{l}.052 \\
(.031)\end{array}$ & + & Conflicting & $\begin{array}{l}.002 \\
(.038)\end{array}$ & + & Interest & $\begin{array}{l}.010 \\
(.043)\end{array}$ \\
\hline \multicolumn{11}{|l|}{$N=240$} \\
\hline $\mathrm{R}^{2}=0.014$ & & & & & & & & & & \\
\hline
\end{tabular}

The negative constant in this equation is meaningful, as it shows that the ad "worked" to significantly reduce incumbent favorability rating among co-partisans. While there is a hint that consistent evaluations may have limited the effectiveness of the ad $(p<.10)$, there is no discernible impact of conflicting evaluations as that coefficient is positive (contrary to expectations) andfalls far short of being statistically significant $(p=.96)$. In other words, our replication for affective ambivalence using the measurement approach employed by Lavine and colleagues (2012) comes no closer than our own analysis to supporting the hypothesis that ambivalence promotes a greater responsiveness by voters to negative campaign messages.

\section{Conclusion}

Amidst the intense ideological and partisan conflict that exists at the elite level in U.S. politics today, and a growing antipathy for the opposition among rank-and-file Republicans and Democrats, it is clear that many citizens possess a mix of positive and negative feelings about the party with which they identify. In this paper, we have tested the idea that such ambivalence reduces the probability of voters employing heuristic thinking when responding to the choices presented to them in political campaigns. According to Lavine, Johnston, and Steenbergen (2012), partisan ambivalence encourages voters to consider their options in a more deliberative (p. 39), objective (p. 37), and rational (p. 122) manner and, in the end, to cast their ballot based less on party and more on issues (p. 179). ${ }^{19}$

If this is true for voting (and our analysis of the 2014 Florida governor's race suggests that it is not), then it should also be true for the manner in which citizens respond to other types of campaign stimuli. Accordingly, we tested the proposition that ambivalence will moderate the effectiveness of the negative attacks (and, specifically, attacks on the candidate of one's own party) that are a defining feature of modern campaigns in the United States today. Even political

\footnotetext{
${ }^{19}$ For a different take on the causal ordering of these variables (ambivalence and the "effortful" processing of information), see Rudolph and Popp (2007).
} 
consultants, who generally believe that negative ads "work," don't believe they always "work" (after all, many candidates who go negative end up losing) or that they "work" equally well among all segments of the electorate. Our expectation was that individuals who possess mixed feelings about their party would be more receptive than others to attacks made against fellow partisans.

In fact, analyses based on three distinct measures of ambivalence (one of which was also adapted so as to permit a replication of the approach used in The Ambivalent Partisan) provided virtually no support for our main hypothesis $(\mathrm{H} 2)$. To be sure, with political scientists having only just begun to scratch the surface in their efforts to understand the nature of ambivalence generally, and of partisan ambivalence, in particular, the findings of any single study should be regarded with a healthy dose of caution. That said, our results are consistent across a range of measures and in two different contexts (a simulated U.S. House race and a real-lifecampaign for governor): There is little to suggest that ambivalence undercuts "the judgmental confidence that citizens typically derive from partisan cues" (Lavine, Johnston, and Steenbergen 2012, 122) and encourages them to consider negatively valenced information that they might otherwise be inclined to reject, distort, or ignore. More generally, it remains to be seen whether feelings of partisan ambivalence affect in a meaningful way how voters respond to the choices presented to them in political campaigns.

This is not, of course, the final word. Future research might want to determine, for example, whether the moderating role of ambivalence varies with the repetition of ads (Fernandes 2013); their timing (Chong and Druckman 2013; Gerber et al. 2011; Hill et al. 2013; Bartels 2014); the degree to which they receive earned media coverage (Ridout and Smith 2008) or are judged by the media to be accurate (Fridkin, Kenney, and Wintersieck 2015); candidate vs. party vs. external sponsorship (Brooks and Murov 2012; Weber, Dunaway, and Johnson 2012; Dowling and Wichowsky 2015); variations in context (Keele and Wolak 2008; Klar 2014; Johnson 2014); and the specific type of ads being examined (e.g., positive rather than negative, policy-rather than performance-based; see Craig and Cossette 2018). For now, however, the jury remains out. 


\section{Bibliography}

Abramowitz, Alan I. 2010. The Disappearing Center: Engaged Citizens, Polarization, and American Democracy. New Haven, CT: Yale University Press.

Achen, Christopher H., and Larry M. Bartels. 2016. Democracy for Realists: Why Elections Do Not Produce Responsive Government. Princeton, NJ: Princeton University Press.

Alvarez, R. Michael, and John Brehm. 1995. "American Ambivalence Towards Abortion Policy: Development of a Heteroskedastic Probit Model of Competing Values." American Journal of Political Science 39 (4): 1055-1082.

Ansolabehere, Stephen, and Shanto Iyengar. 1995. Going Negative: How Political Advertisements Shrink and Polarize the Electorate. New York, NY: Free Press.

Banda, Kevin K., and Jason H. Windett. 2016. "Negative Advertising and the Dynamics of Candidate Support." Political Behavior 38 (3): 747-766.

Bartels, Larry M. 2014. "Remembering to Forget: A Note on the Duration of Campaign Advertising Effects." Political Communication 31 (4): 532-544.

Basinger, Scott J., and Howard Lavine. 2005. "Ambivalence, Information, and Electoral Choice." American Political Science Review 99 (2): 169-184.

Brooks, Deborah Jordan, and Michael Murov. 2012. "Assessing Accountability in a Post-Citizens United Era: The Effects of Attack Ad Sponsorship by Unknown Independent Groups." American Politics Research 40 (3): 383-418.

Campbell, Angus, Philip E. Converse, Warren E. Miller, and Donald E. Stokes. 1960. The American Voter. New York, NY: Wiley.

Chaiken, Shelly, Akiva Liberman, and Alice H. Eagly. 1989. "Heuristic and Systematic Information Processing within and beyond the Persuasion Context." In Unintended Thought, eds. James S. Uleman and John A. Bargh. New York, NY: Guilford Press, pp. 212-252.

Chong, Dennis, and James N. Druckman. 2013. "Counterframing Effects." Journal of Politics 75 (1): 1-16. 
Citrin, Jack, and Samantha Luks. 2005. "Patriotic to the Core? American Ambivalence about America." In Ambivalence and the Structure of Political Opinion, eds. Stephen C. Craig and Michael D. Martinez. New York, NY: Palgrave Macmillan, pp. 127-147.

Craig, Stephen C., and Paulina S. Cossette. 2018 "The Best Defense Is (Or Maybe Isn't) a Good Offense: Should Candidates Respond in Kind to Negative Campaign Attacks?" Paper presented at the 2018 annual meetings of the Midwest Political Science Association.

Craig, Stephen C., James G. Kane, Michael D. Martinez, and Jason Gainous. 2005. "Core Values, Value Conflict, and Citizens' Ambivalence about Gay Rights." Political Research Quarterly 58 (1): 5-17.

Craig, Stephen C., James G. Kane, and Michael D. Martinez. 2002. "Sometimes You Feel Like a Nut, Sometimes You Don't: Citizens' Ambivalence about Abortion." Political Psychology 23 (2): 285-301.

Davis, Nicholas T. 2015. "The Role of Indifference in Split-Ticket Voting." Political Behavior 37 (1): 67-86.

Dowling, Conor M., and Amber Wichowsky. 2015. "Attacks without Consequence? Candidates, Parties, Groups, and the Changing Face of Negative Advertising." American Journal of Political Science 59 (1): 19-36.

Fernandes, Juliana. 2013. "Effects of Political Advertising and Message Repetition on Candidate Evaluation." Mass Communication and Society 16 (2): 268-291.

Festinger, Leon. 1957. A Theory of Cognitive Dissonance. Stanford, CA: Stanford University Press.

Fiorina, Morris P. 2017. Unstable Majorities: Polarization, Party Sorting, and Political Stalemate. Stanford, CA: Hoover Institution Press.

Fowler, Erika Franklin, Michael M. Franz, and Travis N. Ridout. 2016. Political Advertising in the United States. Boulder, CO: Westview Press. 
Franz, Michael M., and Travis N. Ridout. 2007. "Does Political Advertising Persuade?" Political Behavior 29: 465-491.

Fridkin, Kim L., and Patrick J. Kenney. 2004. "Do Negative Messages Work? The Impact of Negativity on Citizens' Evaluations of Candidates." American Politics Research 32: 570605.

Fridkin, Kim Leslie, and Patrick J. Kenney. 2011. "Variability in Citizens' Reactions to Different Types of Negative Campaigns." American Journal of Political Science 55: 307 25.

Fridkin, Kim, Patrick J. Kenney, and Amanda Wintersieck. 2015. "Liar, Liar, Pants on Fire: How Fact-Checking Influences Citizens' Reactions to Negative Advertising." Political Communication 32 (1): 127-151.

Gainous, Jason. 2008. "Who's Ambivalent and Who's Not? Ideology and Ambivalence about Social Welfare." American Politics Research 36 (2): 210-235.

Geer, John G. 2006. In Defense of Negativity: Attack Ads in Presidential Campaigns. Chicago, IL: University of Chicago Press.

Gerber, Alan S., James G. Gimpel, Donald P. Green, and Daron R. Shaw. 2011. "How Large and Long-Lasting are the Persuasive Effects of Televised Campaign Ads? Results from a Randomized Field Experiment." American Political Science Review 105: 135-150.

Greene, Steven H. 2005. "The Structure of Partisan Attitudes: Reexamining Partisan Dimensionality and Ambivalence." Political Psychology 26 (5): 809-822.

Guarana, Cristiano L. and Morela Hernandez. 2016. "Identified Ambivalence: When Cognitive Conflicts Can Help Individuals Overcome Cognitive Traps." Journal of Applied Psychology 101 (7): 1013-1029.

Hill, Seth J., James Lo, Lynn Vavreck, and John Zaller. 2013. "How Quickly We Forget: The Duration of Persuasion Effects from Mass Communication." Political Communication $30(4): 521-547$.

Hill, Seth J., and Chris Tausanovitch. 2015. "A Disconnect in Representation? Comparison of Trends in Congressional and Public Polarization." Journal of Politics 77 (4):1058-1075. 
Hochschild, Jennifer L. 1993. "Disjunction and Ambivalence in Citizens' Political Outlooks." In Reconsidering the Democratic Public, eds. George E. Marcus and Russell L. Hanson. University Park, PA: Pennsylvania State University Press, pp. 187-210.

Huber, Gregory A., and Kevin Arceneaux. 2007. "Identifying the Persuasive Effects of Presidential Advertising." American Journal of Political Science 51: 957-977.

Iyengar, Shanto, and Sean J. Westwood. 2015. "Fear and Loathing across Party Lines: New Evidence on Group Polarization." American Journal of Political Science 59 (3): 690-707.

Johnson, April A. 2014. "Ambivalence, Political Engagement and Context." Political Studies 62 (3): $502-521$.

Jonas, Klaus, Michael Diehl, and Philip Bröemer. 1997. "Effects of Attitudinal Ambivalence on Information Processing and Attitude-Intention Consistency." Journal of Experimental Social Psychology 33 (2): 190-210.

Kaplan, Kalman J. 1972. "On the Ambivalence-Indifference Problem in Attitude Theory and Measurement: A Suggested Modification of the Semantic Differential Technique." Psychological Bulletin 77 (5): 361-372.

Keele, Luke, and Jennifer Wolak. 2008. "Contextual Sources of Ambivalence." Political Psychology 39 (5): 653-673.

Keith, Bruce E., David B. Magleby, Candice J. Nelson, Elizabeth Orr, Mark C. Westlye, and Raymond E. Wolfinger. 1986. "The Partisan Affinities of Independent Leaners." British Journal of Political Science 16 (2): 155-85.

Klar, Samara. 2014. "Partisanship in a Social Setting." American Journal of Political Science 58 (3): 687-704.

Klar, Samara, and Yanna Krupnikov. 2016. Independent Politics: How American Disdain for Parties Leads to Political Inaction. New York, NY: Cambridge UniversityPress.

Kruglanski, Arie W., and Donna M. Webster. 1996. "Motivated Closing of the Mind: 'Seizing' and 'Freezing'." Psychological Review 103 (2): 263-283. 
Lau, Richard R., and Ivy Brown Rovner. 2009. "Negative Campaigning." Annual Review of Political Science 12: 285-306.

Lavine, Howard. 2001. "The Electoral Consequences of Ambivalence toward Presidential Candidates." American Journal of Political Science 45: 915-929.

Lavine, Howard G., Christopher D. Johnston, and Marco R. Steenbergen. 2012. The Ambivalent Partisan: How Critical Loyalty Promotes Democracy. New York, NY: Oxford University Press.

Lipsitz, Keena, and John G. Geer. 2017. "Rethinking the Concept of Negativity: An Empirical Approach. Political Research Quarterly 70 (3): 577-589.

Magleby, David B., and Candice Nelson. 2012. "Independent Leaners as Policy Partisans: An Examination of Party Identification and Policy Views." The Forum 10 (3): Article 6.

Malloy, Liam C., and Shanna Pearson-Merkowitz. 2016. "Going Positive: The Effects of Negative and Positive Advertising on Candidate Success and Voter Turnout." Research and Politics 3 (1); https://journals.sagepub.com/doi/10.1177/2053168015625079 (retrieved 6/1/19).

Martinez, Michael D. 2015. "Do Partisan Voters Trust Party Switchers? A Case Study of the 2014 Florida Gubernatorial Election." Florida Political Chronicle 24 (1): 8-18.

Mason, Lilliana. 2018. Uncivil Agreement: How Politics Became Our Identity. Chicago, IL: University of Chicago Press.

Mattes, Kyle, and David P. Redlawsk. 2014. The Positive Case for Negative Campaigning. Chicago, IL: University of Chicago Press.

Mulligan, Kenneth. 2011. "Partisan Ambivalence, Split-Ticket Voting, and Divided Government." Political Psychology 32 (3): 505-530.

Pew Research Center for the People and the Press. 2017. "The Partisan Divide on Political Values Grows Even Wider"; http://www.people-press.org/2017/10/05/the-partisandivide-on-political-values-grows-even-wider/ (retrieved 6/3/19). 
Ridout, Travis N., and Glen R. Smith. 2008. "Free Advertising: How the Media Amplify Campaign Messages." Political Research Quarterly 61 (4): 598-608.

Rudolph, Thomas J., and Elizabeth Popp. 2007. "An Information Processing Theory of Ambivalence." Political Psychology 28 (5): 563-585.

Sides, John, Michael Tesler, and Lynn Vavreck. 2018. Identity Crisis: The 2016 Presidential Campaign and the Battle for the Meaning of America. Princeton, NJ: Princeton University Press.

Sigelman, Lee, and Mark Kugler. 2003. "Why Is Research on the Effects of Negative Campaigning So Inconclusive? Understanding Citizens' Perceptions of Negativity." Journal of Politics 65: 142- 160.

Stevens, Daniel, Barbara Allen, John Sullivan, and Eric Lawrence. 2015. "Fair's Fair? Principles, Partisanship, and Perceptions of the Fairness of Campaign Rhetoric." British Journal of Political Science 45 (1): 195-213.

Thompson, Megan, Mark P. Zanna, and Dale W. Griffin. 1995. "Let's Not Be Indifferent About (Attitudinal) Ambivalence." In Attitude Strength: Antecedents and Consequences, eds. Richard E. Petty and Jon A. Krosnick. Mahwah, NJ: Lawrence Erlbaum, pp. 361 386.

Thornton, Judd R. 2011. "Ambivalent or Indifferent? Examining the Validity of an Objective Measure of Partisan Ambivalence." Political Psychology 32 (5): 863-884.

Thornton, Judd R. 2014. "Getting Lost on the Way to the Party: Ambivalence, Indifference, and Defection with Evidence from Two Presidential Elections." Social Science Quarterly 95 (1): 184- 201.

Valentino, Nicholas A., Vincent L. Hutchings, and Dmitri Williams. 2004. "The Impact of Political Advertising on Knowledge, Internet Information Seeking, and Candidate Preference." Journal of Communication 54: 337-354.

Weber, Christopher, Johanna Dunaway, and Tyler Johnson. 2012. "It's All in the Name: Cue Ambiguity and the Persuasive Appeal of Campaign Ads." Political Behavior 34 (3): 561 584. 
Zaller, John, and Stanley Feldman. 1992. "A Simple Theory of the Survey Response: Answering Questions versus Revealing Preferences." American Journal of Political Science 36 (3): 579- 616. 